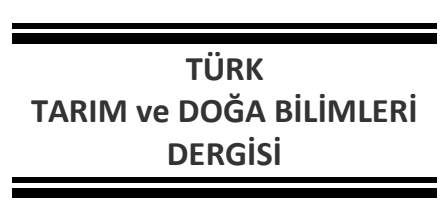

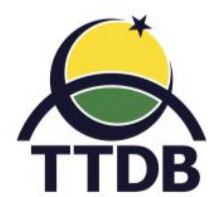

www.dergipark.gov.tr/turkjans

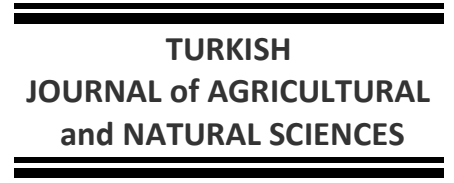

Araştırma Makalesi

\title{
Diyarbakır İlinde Köy Tavukçuluğunun Mevcut Durumu, Sorunları ve Çözüm Önerileri
}

\author{
Hakan INCi ${ }^{1}$, Muhammed Ali EKINCi ${ }^{1}$, Ersin KARAKAYA ${ }^{2 *}$, Tugay AYAŞAN ${ }^{3}$ Hava Şeyma YILMAZ ${ }^{4}$ \\ ${ }^{1}$ Bingöl Üniversitesi Ziraat Fakültesi/ Zootekni Bölümü Bingöl, Türkiye \\ ${ }^{2}$ Bingöl Üniversitesi Ziraat Fakültesi/ Tarım Ekonomisi Bölümü Bingöl, Türkiye \\ ${ }^{3}$ Osmaniye Korkut Ata Üniversitesi Kadirli Uygulamalı Bilimler Yüksekokulu Organik Tarım İşletmeciliği \\ Osmaniye, Türkiye \\ ${ }^{4}$ Kahramanmaraş Sütçü İmam Üniversitesi Bahçe Bitkileri Bölümü Kahramanmaraş, Türkiye
}

*Sorumlu yazar: karakayaersin@hotmail.com

Geliş Tarihi: 06.11.2018

Düzeltme Geliş Tarihi: 04.07.2019

Kabul Tarihi: 31.07.2019

\section{Özet}

$\mathrm{Bu}$ çalışma, Diyarbakır ili köy tavukçuluğunun mevcut durumunun incelenmesi, üreticilerin sosyoekonomik durumları, tavuk barınaklarının durumu, üreticilerin bakım ve besleme konusundaki bilgileri ve üretici sorunlarının ortaya konulması amacıyla yapılmıştır. Çalışmada, basit tesadüfî örnekleme yöntemiyle seçilen köylerde 2016-2017 yılları arasında tavukçuluk yapan işletme sahipleri ile yüz yüze yapılan anketlerden sağlanan veriler analiz edilmiştir. Araştırma bulgularına göre; işletme sahiplerinin yaşlarının ortalamasının 45.8 olduğu, işletmecilerin tamamının okuryazar ve çiftçi olduğu belirlenmiştir. Yetiştiricilerin tamamının erkek olduğu ve kooperatife üye olmadıkları saptanmıştır. Yetiştiricilerin büyük bir kısmının (\%97) tavuk yetiştiriciliği yaptığı belirlenmiştir. İşletmelerin tamamında kanatlı yetiştiriciliği yapıldığı ve kanatlı hayvan sayısının toplam hayvan sayısı içindeki oranının \%59.4 olduğu saptanmıştır. Yetiştiriciler işletmede bulunan tavuk ve horoz ırklarının büyük bir kısmının (\%84) yerel ırk olduğunu ifade etmişlerdir. Yetiştiriciler işletmelerin tamamında hastalık görüldüğünü ifade etmişlerdir. İşletmelerin tamamında yetiştiricilerin sabah, akşam olmak üzere günde iki defa yemleme yaptığı ve hayvanlara fabrika yemi verilme oranının \%34.6 olduğu belirlenmiştir. İşletmelerin tamamında kümes temizliği ve yemleme ve yumurta toplama gibi işlerin kadınlar tarafından yapıldığı belirlenmiştir. İşletmelerin tamamında yetiştiriciler barınakta ilave aydınlatma ve ilave ısıtma yapmadıklarını belirtmişlerdir. Sonuç olarak; Diyarbakır ili köy tavukçuluğunun ülkemizdeki geleneksel köy tavukçuluğunun yapısına benzer olduğu tespit edilmiş, özellikle hastalıklar, uygulanan destekler, yem maliyetinin düşürülmesi ve pazarlama konularındaki sorunlarının çözümü önem taşımaktadır.

Anahtar kelimeler: Diyarbakır, köy tavukçuluğu, bakım- besleme, hastalıklar.

\section{Current Situation, Its Problems and Solution Proposals of Diyarbakır Village Poultry}

\begin{abstract}
This study was carried out to investigate the current status of the village poultry in Diyarbakir province, the socio-economic status of the breeders, the status of the hen houses, the information about the maintenance and feeding of the breeders and the breeders' problems. In the study, the data obtained from face-to-face questionnaires were analyzed with the village poultry breeders in selected villages by simple random sampling method in between 2016-2017. According to research findings; the average age of the breeders are 45.8, and that all of the breeders are literate and farmers. It has been determined that all breeders are male and not cooperative members. It was determined that most of the breeders (97\%) busy with poultry production. It has been determined that all of the plants have breeding poultry, and the ratio of poultry to the total number of animals was $59.4 \%$. The breeders stated that a large proportion (84\%) of Chicken and Rooster races were local races. Breeders stated that all of the enterprises had a disease. In all enterprises, it was determined that the breeders were feeding twice a day in the morning and in the evening and the rate of giving concentrate feed to the animals was $34.6 \%$. It has been determined that the constructions of the poultry house, poultry cleaning and feeding
\end{abstract}


irrigation are done by women entirely. In all enterprises, the breeders stated that they did not provide additional lighting and additional heating in the shelter. As a result; Diyarbakır province village poultry is similar to the structure of the traditional village poultry in our country. Especially diseases, applied supports, reduction of feed cost and solution of problems in marketing matters are important.

Key words: Diyarbakır, village poultry, maintenance, diseases.

\section{Giriş}

Kümes hayvanları yetiştiriciliğinde, pahalı girdi kullanımını gerektiren, buna karşılık verimliliğin yüksek olduğu entansif (yoğun) üretim sistemleri ve verimliliğin düşük olduğu, girdi kullanımının da çok düşük düzeyde olduğu ekstansif (yaygın) üretim sistemi yaygın olarak kullanılmaktadır. Köy tavukçuluğu, aile tavukçuluğu olarak da isimlendirilebilen ekstansif veya yarı entansif tarzda yapılan tavukçuluk özellikle gelir düzeyi düşük kesimler için büyük önem taşımaktadır (Yurt, 2002; Güngördü, 2009). Köy tavukçuluğu; tavuk sayısına ve yetiştirme amacına göre geleneksel köy tavukçuluğu, gelişmiş köy tavukçuluğu ve yarı entansif köy tavukçuluğu olarak gruplandırılabilir (Permin ve ark., 2004; Riise ve ark., 2004; Sonaiya, 2009; Şekeroğlu ve Sarıca, 2010; İnci ve ark., 2015). Geleneksel köy tavukçuluğu daha az hayvan ile kırsal kesimde aile ihtiyacı için yerel ırklarla ek yemleme aşılama vb gibi bakım besleme işlemlerinin yapılmadığı ve ölüm oranının yüksek olduğu üretim sistemidir. Gelişmiş köy tavukçuluğu 10-50 adet hayvanla kırsal kesimde belirli aileler tarafından yapılan aile içi tüketim fazlasının gelire dönüştürüldüğü, kültür ırklarının da kullanıldığı belli seviyede bakım ve besleme işlemlerinin yapıldığı üretim sistemidir. Yarı entansif üretim sistemi ise 50-200 hayvan ile kırsal kesimde çok az aile tarafından yapılan ticari bir faaliyettir. Bütün bakım ve besleme işlemlerinin tam yapıldığı ölüm oranının düşük olduğu ve hibritlerin kullanıldığı üretim sistemidir (Güngördü ve Çelen 2018). Köy tavukçuluğu aile ihtiyacı için et-yumurta üretmek ve üretim fazlasıyla da küçük bazı ihtiyaçları karşılamak amacıyla yapıldığı için özellikle kırsal kesimdeki ailelerin geçinmelerinde çok önemli bir üretim kaynağıdır. Bununla birlikte birçok yörede endüstriyel üretimden sağlanan damızlıklarla köy tavukçuluğu yapıldığı bilinmektedir. Ayrıca doğal gurkluk yoluyla damızlık üretiminin devam ettirildiği yörelerde bulunmaktadır (Türkoğlu ve Eleroğlu, 1999). Köy tavukçuluğu yapan işletmeler genel olarak kırsal kesimde yer alır ve büyük çoğunluğu aile işletmeleridir ve genellikle çocuklar ve kadınlar tarafından yapılmaktadır (Copland ve Alders, 2005). TÜik (2018) yılı verilerine göre, Türkiye toplam kümes hayvanları sayısı 359217862 adet olarak hesaplanmış olup bunun \%63.8'ini et tavuğu (229 506689 adet), \%34.5'ini yumurta tavuğu (124 054810 adet), \%1.1'ini hindi (4 043332 adet), $\% 0.3^{\prime}$ ünü kaz (1 080190 adet) ve \%0.1'ini ise ördek (532 841 adet) oluşturmaktadır.

Tablo 1. Diyarbakır ilinde ilçeler itibariyle mevcut tavuk sayıları

\begin{tabular}{lcccc}
\hline \multirow{2}{*}{ ilçeler } & \multicolumn{4}{c}{ Mevcut sayı (2018) } \\
\cline { 2 - 5 } & Et tavuğu & Oran (\%) & Yumurta tavuğu & Oran (\%) \\
\hline Bağlar & & 15100 & 3.1 \\
Bismil & & 168000 & 34.7 \\
Çermik & & 63200 & 13.0 \\
Çınar & & 55250 & 11.4 \\
Çüngüş & & 1200 & 0.2 \\
Dicle & & & 6500 & 1.3 \\
Eğil & 1000 & 0.5 & 11000 & 2.2 \\
Ergani & & 23306 & 4.8 \\
Hani & 591.5 & 26500 & 5.4 \\
Hazro & & 6400 & 1.3 \\
Kayapınar & & & 12000 & 2.4 \\
Kocaköy & & 7700 & 1.5 \\
Kulp & 15000 & & 9184 & 1.9 \\
Lice & & & 15500 & 3.2 \\
Silvan & 2200 & 1.1 & 7500 & 1.5 \\
Sur & & & 26000 & 5.3 \\
Yenişehir & 40.000 & 21.3 & 28512 & 5.9 \\
\hline Toplam & & & 482852 & 100.0 \\
\hline
\end{tabular}


Tablo 1'de Diyarbakır iline bağıı ilçelerde et ve yumurta tavuğu mevcut sayıları verilmiştir. Tüik (2018) yılı verilerine göre, Diyarbakır ilinde toplam yumurta tavuğu 482852 adet iken toplam et tavuğu 187308 adet olarak saptanmıştır. Et tavuğu yetiştiriciliğinin Yenişehir (\%37.3) ve Ergani (\%31.5), yumurta tavuğu yetiştiriciliğinin ise en yüksek oranda (\%34.7) Bismil ilçesinde yapıldığı belirlenmiştir.

Kırsal kesimde, tavuk yetiştiriciliği diğer tarımsal faaliyetler içerisinde ikinci derecede öneme sahip olmasına rağmen, özellikle üreticilerin hayvansal protein ihtiyacının \%30'dan fazlasını karşılaması ve elde edilen fazla ürünlerin satılarak aile bütçesine gelir sağlaması bakımından köy tavukçuluğu yetiştiriciliği son derece önemlidir (FAO, 2008; Şekeroğlu ve Sarıca, 2010; İnci ve ark., 2015).

Bu çalışma, Diyarbakır illi köy tavukçuluğunun mevcut durumunun araştırılması ve yetiştiricilerin sorunlarının belirlenerek bu sorunlara ait öneriler geliştirilmesi amacıyla yapılmıştır.

\section{Materyal ve Yöntem}

$$
n=\frac{N^{*} p * q}{(N-1)^{*} \alpha^{2} p+p * q}=\frac{650 * 0,5 * 0,5}{650 *(0,0346)^{2}+0,5 * 0,5}=
$$

Formülde;

n: Örnek büyüklüğü,

$\mathrm{N}$ : Populasyondaki işletme sayısı,

$\alpha_{p}^{2}$ : Oranın varyansı,

$r$ : Ortalamadan sapma (\%5),

$\alpha^{2} p=r / z \alpha / 2$

Maksimum örnek hacmine ulaşmak için $P=$ 0,5 olarak alınmıştır. P'nin 0,5'ten daha az veya daha yüksek değerleri örnek hacmini düşürür. O nedenle P'nin bilinmediği durumlarda maksimum örnek hacmiyle çalışmak olası hatayı azaltacağından $P=0,5$ alınmıştır. Diyarbakır tarım il müdürlüğü (2016) verilerinden faydalanılarak seçilen alt bölgelerdeki toplam köy tavukçuluğu yapan işletme sayısı 650 adet olarak belirlenmiş, ilçelerdeki işletmelerin toplam işletmeler içindeki oranları ve yapılan anket sayıları Tablo 2'de verilmiştir. \%95 güven aralığında ve ortalamadan $\% 5$ sapma ile anket sayısı 159 olarak tespit edilmiştir. Bağlar ilçesinde 7 köyde 20 adet, Bismil ilçesinde 7 köyde 24 adet, Çınar ilçesinde 7 köyde 20 adet, Ergani ilçesinde 5 köyde 16 adet, Kayapınar ilçesinde 5 köyde 21 adet, Silvan ilçesinde 5 köyde 18 adet, Sur ilçesinde 6 köyde 22 adet ve Yenişehir ilçesinde 5 köyde 18 adet anket yapılmıştır. Elde edilen veriler varyans analiz yöntemine göre analiz edilmiştir. Ortalamaların karşılaştırılması Duncan çoklu karşılaştırma testi
$\mathrm{Bu}$ araştırmanın ana materyalini Diyarbakır ilinde yetiştiriciliği yapan işletmelerden yüz yüze elde edilen veriler oluşturmuştur. Bu işletmelerden 2017 yılında anket yoluyla toplanan veriler değerlendirilmiştir. İşletmelerin sosyo-ekonomik özellikleri, işletme sahiplerinin temel hayvancılık bilgileri, işletmelerin yapısal özellikleri, bakımbesleme uygulamaları gibi örnek sorular içeren anket formları, yüz yüze yapılan görüşmelerde doldurulmuş ve anket verileri il geneli ve ilçeler itibariyle değerlendirilmiştir. Farklı yörelerdeki aynı tür işletmelerle karşılaştırma yapabilmek amacıyla konu ile ilgili diğer çalışmalar incelenmiş ve bulgularından faydalanılmıştır. Ayrıca, Diyarbakır iı Tarım ve Orman Müdürlüğü ve ilçe Tarım Müdürlüklerine ait kayıtlardan faydalanılmıştır. Bu kaynaklar hem ana materyalin oluşmasında, hem de bulguların ortaya konmasında destek sağlayan veriler niteliğindedir.

Araştırmanın anket sayısı Oransal Örnekleme Yöntemi ile tespit edilmiştir. Örnek hacminin hesaplanmasında aşağıdaki formül kullanılmıştır.

kullanılarak yapılmıştır. Verilerin istatistiki olarak değerlendirilmesinde SPSS (2017) paket programı kullanılmıştır.

Tablo 2. Incelenen işletmelerin belirlenen ilçelere göre dağılımı

\begin{tabular}{lcc}
\hline ilçeler & $\begin{array}{c}\text { Anket Yapılacak } \\
\text { Işletme Sayısı }\end{array}$ & $\begin{array}{c}\text { Işletme } \\
\text { Oranı }\end{array}$ \\
\hline Bağlar & 20 & 12.5 \\
Bismil & 24 & 15.4 \\
Çınar & 20 & 12.5 \\
Ergani & 16 & 10.0 \\
Kayapınar & 21 & 13.2 \\
Silvan & 18 & 11.3 \\
Sur & 22 & 13.8 \\
Yenişehir & 18 & 11.3 \\
\hline Toplam & $\mathbf{1 5 9}$ & $\mathbf{1 0 0 . 0}$ \\
\hline
\end{tabular}

\section{Bulgular ve Tartışma \\ Yetiştiricilerin sosyo-demografik özellikleri}

Yetiştiricilerin \%44,7'sinin 40-50 yaş arasında olduğu, \%32,1'inin 51 yaş ve üzerinde olduğu, $\% 23,3$ 'ünün ise 40 yaşın altında olduğu, yetiştiricilerin tamamının okuryazar ve çiftçi olduğu belirlenmiştir. Yetiştiricilerin tamamının erkek olduğu ve kooperatif üyesi olmadıkları sonucu belirlenmiştir. Demirulus ve ark. (2013) yürüttükleri çalışmada erkek yetiştiricilerin oranını Diyarbakır ve Tekirdağ illeri için sırasıyla; \%84 ve \%24 olarak Bural 
(2015) ise Bingöl ili için bu oranı \%75.7 olarak bildirmişlerdir. Çalışmada bulduğumuz sonuç, Demirulus ve ark (2013) ve Bural (2015)'ın çalışma bulgularından farklı bir sonuç ortaya koymuş, köy tavukçuluğunun Diyarbakır ilinde genellikle erkek yetiştiriciler tarafından yapıldığı sonucuna varılmıştır. Güngördü (2009), tarafından yapılan çalışmada, yetiştiricilerin eğitim düzeylerine göre dağılımı incelendiğinde en yüksek oranı \%73.2 ile ilkokul mezunlarının oluşturduğu, Bural (2015) tarafından yapılan çalışmada ise, en yüksek oranın \%69.2 ile okumamış yetiştirici grubunda olduğu ve yetiştiricilerin büyük oranda (\%59.5) çiftçi oldukları sonucu saptanmıştır. Yetiştiricilerin eğitim durumlarıyla ilgili çalışmada bulduğumuz sonuçlar Güngördü (2009)'nün çalışma bulgularıyla farklı, Bural (2015)'ın çalışma bulgularıyla ise benzer sonuç ortaya koymuş ve köy tavukçuluğu yetiştiriciliğinin genellikle eğitim seviyesi düşük kişiler tarafından yapıldığı kanısına varılmıştır.

\section{Köy tavukçuluğunda üretimi terk etme durumu}

Yetiştiricilerin büyük bir kısmının (\%97) köy tavukçuluğu yetiştiriciliği yaptığı, \%3'ünün ise hastalıklardan dolayı yetiştiriciliği bıraktıkları belirlenmiştir. Köy tavukçuluğunun yapılma nedeni olarak, diğer (alışkanlık, hobi vb.) nedenlerden dolayı yapan yetiştirici oranı \%89.3, ekonomik getiriden dolayı köy tavukçuluğu yapan yetiştirici oranı \%5.7 ve geleneksel olduğundan dolayı yapan yetiştirici oranı ise \%1.9 olarak belirlenmiştir.

\section{İsletmelerde bulunan kanatlı hayvan sayısının dağılımı}

İşletmelerde kanatlı hayvan sayısının toplam hayvan sayısı içindeki oranı \%59.4 olarak hesaplanmıştır. İşletmelerin \%32'sinde (51 işletmede) kanatlı hayvan sayısı $\leq 50$ adet, $\% 42.7$ 'sinde (68 işletme) kanatlı hayvan sayısı 51100 adet ve \%25.3'ünde (40 işletme) kanatı ıayvan sayısı $\geq 101$ adet olarak belirlenmiştir. İlçeler itibariyle kanatlı hayvan sayısının dağılımı incelendiğinde, Bağlar ilçesinde $\leq 50$ adet kanatlı hayvan yetiştiren kimse olmadığı, Silvan ilçesinde ise $\geq 101$ adet kanatlı hayvan yetiştiren kimse olmadığı sonucu görülmüştür. Ergani ilçesindeki yetiştiricilerin tamamı $\leq 50$ adet kanatlı hayvan yetiştirdiklerini ifade etmişlerdir (Tablo 3).

Tablo 3. Anket yapılan ilçeler itibariyle kanatlı hayvan sayısının dağılımı

\begin{tabular}{lcccccccccc}
\hline \multirow{2}{*}{ Kanatlı hayvan sayısı (adet) } & \multicolumn{10}{c}{ ìlçeler } \\
\cline { 2 - 11 } & Bağlar & Bismil & Çınar & Ergani & Kayapınar & Silvan & Sur & Yenişehir & Toplam \\
\hline 50 & 0 & 8 & 15 & 16 & 5 & 4 & 2 & 1 & 51 \\
$51-100$ & 6 & 9 & 1 & 0 & 11 & 14 & 16 & 11 & 68 \\
$\geq 101$ & 14 & 7 & 4 & 0 & 5 & 0 & 4 & 6 & 40 \\
\hline Toplam & 20 & 24 & 20 & 16 & 21 & 18 & 22 & 18 & 159 \\
\hline
\end{tabular}

\section{Işletmelerde bulunan tavuk ve horoz ırkları}

İsletmede bulunan tavuk ve horozların ırklarının dağılımına bakıldığında, büyük bir kısmının (\%84) karışık köy sürüleri olduğu tespit edilmiştir. İşletmelerde ticari yumurtacı hibrit genotiplerinin bulunma oranı \%7, hem yerel hem de ticari yumurtacı hibrit genotiplerin bulunma oranı ise $\% 9$ olarak belirlenmiştir. Bayraktar (2012) tarafından Artvin'de yapılmış olan çalışmada, yerli, ticari yumurtacı ve karışık genotiplerin yetiştirilme oranları bakımından bütün bölgelerde yerli genotiplerin tercih edildiği belirlenmiştir. Artvin bölgesinde yerli genotipleri tercih edenler \%83.76, ticari yumurtacı \%12.12 ve karışık \%4.11 olarak bildirilmiştir. Çalışma bulguları işletmede bulunan ırklar itibariyle diğer çalışma bulgularıyla kısmen benzer bulunmuş ve sonuç olarak Diyarbakır ili köy tavukçuluğunun geleneksel köy tavukçuluğu yapısında olduğu kanısına varılmıştır.
İsletmelerde bulunan tavuk ve horoz sayılarının ilçeler itibariyle dağılımı

Incelenen işletmelerde 20 haftadan büyük tavuk sayısı 4 ile 45 adet arasında değişirken ortalama 19 adet olarak, 20 haftadan büyük horoz sayısı 0 ile 8 adet arasında ve ortalama 2,6 adet, 919 haftalık piliç sayısı 5 ile 130 adet ve ortalama 31,2 adet, 0-8 haftalık civciv sayısı 3 ile 110 adet arasında ve ortalama 27,9 adet olarak tespit edilmiştir (Tablo 4).

Tablo 4. Farklı yaşlardaki kanatlı hayvanların sayısı

\begin{tabular}{lcccc}
\hline Tavuk & $\begin{array}{c}\mathbf{2 0} \\
\text { yaşı } \\
\text { büyük } \\
\text { tavuk }\end{array}$ & $\begin{array}{c}\mathbf{2 0} \\
\text { haftadan } \\
\text { büyük } \\
\text { horoz }\end{array}$ & $\begin{array}{c}\mathbf{9 - 1 9} \\
\text { hafta } \\
\text { piliç }\end{array}$ & $\begin{array}{c}\mathbf{0 - 8} \\
\text { hafta } \\
\text { civciv }\end{array}$ \\
\hline Ortalama & 19.01 & 2.67 & 31.25 & 27.91 \\
Minimum & 4 & 0 & 5 & 3 \\
Maximum & 45 & 8 & 130 & 110 \\
\hline
\end{tabular}


Kanatlı hayvan sayılarının ilçeler itibariyle dağılımı tablo 5'te verilmiştir. 20 haftadan büyük tavuk sayısı ortalaması tüm ilçeler genelinde 19 adet olarak hesaplanmıştır. 20 haftadan büyük tavuk sayısı ortalaması bakımından işletmelerin 5 gruba ayrıldığı belirlenmiştir. Ergani ilçesinde 20 haftadan büyük tavuk sayısı ortalaması en az (9.5), Yenişehir'de ise en fazla (27.5) olarak tespit edilmiştir. 20 haftadan büyük tavuk sayısı ortalamaları arasındaki farklar ilçeler itibariyle istatistiki olarak önemli bulunmuştur $(P<0.05)$. Tüm işletmeler genelinde 20 haftadan büyük horoz sayısının ortalaması 2,6 adet olarak hesaplanmıştır. 20 haftadan büyük horoz sayısının ortalaması açısından işletmelerin 6 gruba ayrıldığı, en yüksek değerin 5.8 adet ile Silvan ilçesinde, en düşük değerin ise 0.9 ile Ergani'de olduğu belirlenmiştir. 20 haftadan büyük horoz sayısı ortalamaları arasındaki farklar ilçeler itibariyle istatistiki olarak önemli bulunmuştur $(\mathrm{P}<0.05)$. 9-19 haftalık piliç sayısı ortalamaları arasındaki farklar ilçeler itibariyle istatistiki olarak önemli bulunmuş $(P<0.05)$, tüm işletmeler itibariyle 9-19 haftalık piliç sayısı ortalaması 31.2 adet olarak belirlenmiştir. 9-19 haftalık piliç sayısı ortalaması bakımından işletmelerin 4 gruba ayrıldığı belirlenmiştir. Ergani ilçesinde 9-19 haftalık piliç sayısı ortalaması 10.5 adet iken, Bağlar ilçesinde 63 adet olarak bulunmuştur. Ortalama 0-8 hafta civciv sayısının tüm işletmeler genelinde 27.9 adet olduğu, bu değerin Bağlar ilçesinde 54,6 adet ile en yüksek değeri aldığı, Ergani ilçesinde ise 8.5 adet ile en düşük değeri aldığı sonucu saptanmıştır. 0-8 hafta civciv sayısı ortalaması bakımından işletmelerin 6 gruba ayrıldığı tespit edilmiş ve $0-8$ hafta civciv sayısı ortalamaları arasındaki farklar ilçeler itibariyle istatistiki olarak önemli bulunmuştur $(\mathrm{P}<0.05)$.

Tablo 5. Kanatlı hayvan sayılarıyla işletmeler arasındaki ilişki

\begin{tabular}{lcccc}
\hline İçeler & $\begin{array}{c}\mathbf{2 0} \\
\text { haftadan } \\
\text { büyük } \\
\text { tavuk } \\
\text { sayısı }\end{array}$ & $\begin{array}{c}\mathbf{2 0} \\
\text { haftadan } \\
\text { büyük } \\
\text { horoz } \\
\text { sayısı }\end{array}$ & $\begin{array}{c}\mathbf{9 - 1 9} \\
\text { hafta } \\
\text { piliç } \\
\text { sayısı }\end{array}$ & $\begin{array}{c}\mathbf{0 - 8} \\
\text { hafta } \\
\text { civciv } \\
\text { sayısı }\end{array}$ \\
\hline Bağlar & $20.0^{\mathrm{c}}$ & $2.9^{\mathrm{cd}}$ & $63.0^{\mathrm{c}}$ & $54.6^{\mathrm{d}}$ \\
Bismil & $18.9^{\mathrm{bc}}$ & $1.8^{\mathrm{b}}$ & $30.1^{\mathrm{b}}$ & $26.0^{\mathrm{bc}}$ \\
Çınar & $14.4^{\mathrm{b}}$ & $1.7^{\mathrm{b}}$ & $25.5^{\mathrm{b}}$ & $21.7^{\mathrm{b}}$ \\
Ergani & $9.5^{\mathrm{a}}$ & $0.9^{\mathrm{a}}$ & $10.5^{\mathrm{a}}$ & $8.5^{\mathrm{a}}$ \\
Kayapınar & $18.2^{\mathrm{bc}}$ & $2.3^{\mathrm{bc}}$ & $30.6^{\mathrm{b}}$ & $26.4^{\mathrm{bc}}$ \\
Silvan & $16.6^{\mathrm{bc}}$ & $5.8^{\mathrm{e}}$ & $20.9^{\mathrm{ab}}$ & $18.9^{\mathrm{ab}}$ \\
Sur & $24.9^{\mathrm{d}}$ & $3.0^{\mathrm{d}}$ & $30.3^{\mathrm{b}}$ & $28.8^{\mathrm{bc}}$ \\
Yenişehir & $27.5^{\mathrm{d}}$ & $2.7^{\mathrm{cd}}$ & $34.2^{\mathrm{b}}$ & $34.2^{\mathrm{c}}$ \\
\hline Toplam & 19.0 & 2.6 & 31.2 & $27.0^{2}$ \\
\hline
\end{tabular}

\begin{tabular}{|c|c|c|c|c|}
\hline İlçeler & $\begin{array}{c}20 \\
\text { haftadan } \\
\text { büyük } \\
\text { tavuk } \\
\text { sayısı }\end{array}$ & $\begin{array}{c}20 \\
\text { haftadan } \\
\text { büyük } \\
\text { horoz } \\
\text { sayısı }\end{array}$ & $\begin{array}{c}\text { 9-19 } \\
\text { hafta } \\
\text { piliç } \\
\text { sayısı }\end{array}$ & $\begin{array}{c}0-8 \\
\text { hafta } \\
\text { civciv } \\
\text { sayısı }\end{array}$ \\
\hline Bağlar & $20.0^{c}$ & $2.9^{\mathrm{cd}}$ & $63.0^{c}$ & $54.6^{d}$ \\
\hline Bismil & $18.9^{b c}$ & $1.8^{\mathrm{b}}$ & $30.1^{b}$ & $26.0^{\mathrm{bc}}$ \\
\hline Çınar & $14.4^{\mathrm{b}}$ & $1.7^{b}$ & $25.5^{b}$ & $21.7^{\mathrm{b}}$ \\
\hline Ergani & $9.5^{\mathrm{a}}$ & $0.9^{\mathrm{a}}$ & $10.5^{\mathrm{a}}$ & $8.5^{\mathrm{a}}$ \\
\hline Kayapınar & $18.2^{\mathrm{bc}}$ & $2.3^{b c}$ & $30.6^{b}$ & $26.4^{b c}$ \\
\hline Silvan & $16.6^{b c}$ & $5.8^{e}$ & $20.9^{\mathrm{ab}}$ & $18.9^{\mathrm{ab}}$ \\
\hline Sur & $24.9^{d}$ & $3.0^{d}$ & $30.3^{b}$ & $28.8^{b c}$ \\
\hline Yenişehir & $27.5^{d}$ & $2.7^{c d}$ & $34.2^{b}$ & $34.2^{c}$ \\
\hline $\begin{array}{l}F \text { ve } P \\
\text { değeri }\end{array}$ & $\begin{array}{c}11.169 \\
0.000 * * *\end{array}$ & $\begin{array}{c}40.495 \\
0.000^{*} * *\end{array}$ & $\begin{array}{c}12.125 \\
0.000^{* * *}\end{array}$ & $\begin{array}{c}9.874 ; \\
0.000 * * *\end{array}$ \\
\hline
\end{tabular}

a,ab,b,bc,c,cd,d,e: Aynı sütunda farklı harflerle gösterilen ortalamalar arasındaki farklılıklar istatistiki olarak önemlidir.

$* * *: \mathrm{P}<0.001$

\section{Işletmelerdeki tavuklarda görülen hastalıklar}

İsletmelerin tamamında hastalık görüldüğü sonucu saptanmıştır. İşletmelerin yaklaşık \%70'inde sürünün yarısından çoğunun öldüğü, \%30'unda ise yarısından azının öldüğü sonucu saptanmıştır. Şekeroğlu ve Akşimşek (2009) tarafından yapılan çalışmada, işletmelerin \%98.9'unda sürünün hepsinin öldüğü, \%1.1'inde yarıdan fazlasının öldüğü belirtilmiştir. Bural (2015) yaptığı çalışmada, işletmelerin \%53.2'sinde sürünün hepsinin öldüğü, \%37.2'sinde yarıdan fazlasının öldüğü, \%8.3'ünde yarısından azının öldüğü ve \%1.3'ünde ise hayvanlarda ölüm görülmediği belirlenmiştir.

\section{Işletmelerde yapılan yemleme türü}

İncelenen işletmelerde hayvanlara \%52.8 oranında karışık yemleme yapıldığı, \%50.9 oranında buğday verildiği, \%46.5 oranında mısır ve arpa verildiği ve \%34.6 oranında ise standart fabrika yemi verildiği belirlenmiştir. Şekeroğlu ve Akşimşek (2007) yaptıkları çalışmada, kümes hayvanlarının yemlenmesinde buğday, karışık yem (buğday, arpa, mısır, ev artıkları) ve standart yemlerin kullanımını sırasıyla; \%65.7, \%34.3 ve \%0 olarak tespit etmişlerdir. Güngördü (2009) tarafından Batman ilinde yapılan diğer bir çalışmada da, kümes hayvanlarının yetiştirilmesinde fabrika yeminin hiç kullanılmadığı ve tavukların beslenmesinde daha çok (\%36) Dane Yem + Otlatma + Artıkların kullanıldığı saptanmıştır. Bingöl'de Bural (2015) ve İnci ve ark (2015) tarafından yapılan çalışmalarda işletmelerde hayvanların beslenmesinde oransal olarak \%91 artıkların, \%59 otlatmanın, \%28.2 dane yemin, \%2.6 diğer yem kaynaklarının ve \%1.3 
fabrika yeminin kullanıldığı belirlenmiştir. Çalışmada bulunan fabrika yemi kullanım oranının diğer çalışmalarda bulunan değerlerden oldukça yüksek olduğu görülmektedir. İşletmelerin tamamında yemlemenin sabah, akşam olmak üzere günde 2 defa yapıldığı sonucu belirlenmiştir. Bingöl'de Bural (2015) ve İnci ve ark. (2015) tarafından yapılan çalışmalarda yemlemenin genel olarak \%99.4 ve \%96.8 oranla sabah ve akşam olmak üzere günde 2 kez yapıldığı, öğlen yemleme yapan yetiştirici oranın ise \%21.2 olduğu belirlenmiştir. Yemlemenin ne zaman yapıldığına dair elde edilen çalışma bulguları, Bural (2015) ve Inci ve ark. (2015)'nin çalışma bulgularıyla tamamen benzer niteliktedir.

\section{Kümes işlerinin aile bireyleri tarafından yapılma durumu}

İşletmelerin tamamında kümesin yapımı, kümes temizliğinin yapılması ve yemleme sulama gibi işlerin kadınlar tarafından yapıldığı belirlenmiştir. Tokat'ta yapılan bir çalışmada, barınak yapımının erkekler tarafından (\%97.5), barınak temizliğinin kadınlar tarafından (\%90.2), yemleme ve sulamanın kadınlar tarafından (\%59.3) gerçekleştirildiği belirlenmiştir. Artvin'de Bayraktar (2012) tarafından yapılan çalışmada, barınak yapımının \%42.1 oranında erkekler tarafından, barınak temizliğinin \%68.3 oranında kadınlar tarafından ve yemleme sulama işlerinin \%69.5 oranında kadınlar tarafından yapıldığı belirlenmiştir. Eleroğlu ve ark. (2014) tarafından Sivas ili AgroEkolojik Alt Bölgelerinde yapılan çalışmada Yemleme-sulama işlemlerinde \%65.6 oranında kadınların birincil etken olduğu saptanmıştır. Bural (2015) tarafından yapılan çalışmada, yetiştiricilik yapan ailelerde kadınların kümes işlerine katılma oranı ortalama \%46 olarak bulunmuştur. Diyarbakır ili köy tavukçuluğunda barınak yapımının tamamen kadınlar tarafından yapılması diğer çalışma sonuçlarından farklı bir durum ortaya koymuştur. Illaveten, barınak işlerinde görev dağılımı bakımından tamamen kadınların etkin olması sonucu Eku ve ark. (2002), ve Akşimşek (2008)'e göre; "barınak temizliğini, yemleme ve sulama işlerini kadınların üstlenmesi köy tavukçuluğu işletmelerinin genel özelliklerindendir" görüşünü destekler niteliktedir. İşletmelerin tamamında barınakta ilave aydınlatma ve ilave ısıtma yapılmadığı belirlenmiştir. İşletmelerin tamamında barınakta ilave havalandırmanın pencereden sağlandığı sonucu tespit edilmiştir. Akşimşek (2008) tarafından yapılan çalışmada, işletmelerin \%94'ünde Bayraktar (2012)'ın yapmış olduğu çalışmada ise işletmelerin tamamında ilave aydınlatma ve ilave ısıtma yapılmadığı belirlenmiştir. Bütün çalışmaların genel sonucu olarak geleneksel köy tavukçuluğunda ilave aydınlatma ve ilave ısıtmanın olmadığı işletmelerin gün uzunluğundan yetindikleri sonucu itibariyle çalışma bulguları uyumlu olarak ortaya çıkmıştır.

\section{Sonuç ve Öneriler}

Araştırma sonuçlarına göre; Diyarbakır ili köy tavukçuluğunun tamamı okuryazar, çiftçi ve kooperatife üye olmayan erkek yetiştiriciler tarafından yapıldığı ve Türkiye'deki geleneksel köy tavukçuluğu yapısında olduğu görülmüş, özellikle hastalıklar konusundaki sorunlarının çözümü önem taşımaktadır. İşletmelerde kullanılan tavuk ve horoz ırklarının geleneksel köy tavukçuluğu yapısından, gelişmiş köy tavukçuluğu yapısına çıkabilmesi için işletmecilerin köy tavukçuluğu konusundaki eğitim düzeylerinin yükseltilmesi ve yetiştiricilik konusundaki kurs ve seminerlerin daha fazla düzenlenmesi gerekmektedir. Fabrika yeminin yemlemede kullanılma oranın düşürülmesi için alternatif yem kaynaklarının daha etkin kullanıması, hastalıklar konusunda gerekli önlemlerin önceden alınması ve devamlılığının sağlanması yetiştiricilik açısından daha verimli ve ekonomik bir durumun ortaya çıkması için son derece önemlidir. Diyarbakır ilinin köylerinde sağlık ve kümes koşullarının iyileştirilmesi ve üretimde devamlılığın sağlanabilmesi konusunda gerekli çalışmaların ve önerilerin yapılması gerekmektedir. Yetiştiricilerin örgütlenme noktasında teşviklerinin arttırılması gerekmekte, bu sayede bazı sorunlara daha kolay ve daha hızlı çözüm bulmaları sağlanmalıdır. Yapılacak devlet destekleri ve iyileştirici politikalar sayesinde bölge tavukçuluğunda daha fazla verimin elde edilmesi sağlanabilir. Gelişmiş köy tavukçuluğu ve yarı entansif köy tavukçuluğu üretim sistemine geçişin sağlanabilmesi için modern ekipmanların kullanılması, hastalıklara karşı koruyucu tedbirlerin alınması, ayrıca yetiştirme tekniklerinin uygulanması gerekmektedir.

\section{Teşekkür}

Bu çalışmada, 2731732 kod numarasıyla Bingöl Üniversitesi Ziraat Fakültesi ile Diyarbakır ì Tarım ve Orman Müdürlüğü arasında 07.04.2017 tarihinde Ortak Araştırma ve Geliştirme (AR-GE) proje protokolü çerçevesinde yürütülen ve tamamlanan proje verilerinin bir kısmı kullanılmıştır.

\section{Kaynaklar}

Akşimşek, Ş.D. 2008. Ülkemizde Kuş Gribi Görülmesinden Sonra Tokat illi Köy Tavukçuluğunun Yapısı. Yüksek Lisans Tezi, Gaziosmanpaşa Üniversitesi Fen Bilimleri Enstitüsü, Tokat. 
Bayraktar, E. 2012. Artvin ili Köy Tavukçuluğunun Yapısı. Yüksek Lisans Tezi, Gaziosmanpaşa Üniversitesi Fen Bilimleri Enstitüsü, Tokat.

Bural, R. 2015. Bingöl ili Köy Tavukçuluğunun Yapısı. Yüksek Lisans Tezi, Bingöl Üniversitesi Fen Bilimleri Enstitüsü, Bingöl.

Copland, J.W., Alders, R.G. 2005. The Australian village poultry development program in Asia and Africa. World's Poultry Science Journal, 61: 31-37.

Demirulus, H., Aydın, A., Beşkaya, S., Dursun, S.G. 2013. Geliştirilmesi açısından Diyarbakır ve Tekirdağ illerinde köy tavukçuluğunun durumunu belirlemeye yönelik karşılaştırmalı bir çalışma. 8. Ulusal Zootekni Bilim Kongresi, 5-7 Eylül, Çanakkale, s. 146156.

Ekue, F.N., Poné, K.D., Mafeni, M.J., Nfi, A.N., Njoya, J. 2002. Survey of the Traditional Poultry Production System in the Bamenda Area, Cameroon. In: Characteristics and Parameters of Family Poultry Production in Africa, IAEA, Vienna), pp.15-25.

Eleroğlu, H., Yıldırım, A., Şekeroğlu, A. 2014. Sivas ili agro-ekolojik alt bölgelerinde köy tavukçuluğunun yapısı. Tavukçuluk Araştırma Dergisi, 11(2): 10-15.

FAO, 2008. FAOSTAT, Statistical Database of Food and Agriculture Organization of the United Nations, Rome-Italy.

Güngördü, S. 2009. Batman illi Köy Tavukçuluğunun Durumu. Yüksek Lisans Tezi, Yüzüncü Yıl Üniversitesi Fen Bilimleri Enstitüsü, Van.

Güngördü, S., Çelen, M.F. 2018. Batman ili köy tavukçuluğunun durumu. Batman Üniversitesi Yaşam Bilimleri Dergisi, 8(2/2): 37-59.

İnci, H., Bural, R., Şengül, T. 2015. Bingöl ili köy tavukçuluğunun yapısı. Tavukçuluk Araştırma Dergisi, 12(2): 13-17.

Permin, A., Riise, J.C., Kryger, K.N. 2004. Strategies for developing family poultry production at village level. Experiences from West Africa and Asia. World Poultry Congress, 8-13 June, Istanbul-Turkey, pp. 115-125.

Riise, J.C., Permin, A., Mcainsh, C.V., Frederiksen, L. 2004. Keeping Village Poultry a Technical Manual on Small-Scale Poultry Production. Network for Small holder Poultry Development. Copenhagen, Denmark.

Sonaiya, E.B., 2009. Some technical and socioeconomic factors affecting productivity and profitability of small holder family poultry. World's Poultry Science Journal, 65: 201-205.
Şekeroğlu, A., Akşimşek, Ş.D. 2007. Tokat ilinde köy tavukçuluğunun yapısı. 5. Ulusal Zootekni Bilim Kongresi, 5-8 Eylül, Van, s. 126-136.

Şekeroğlu, A., Akşimşek, D.Ş. 2009. Tokat ili köy tavukçuluğunun bazı özellikleri. Anadolu Tarım Bilimleri Dergisi, 24(2): 108-113.

Şekeroğlu, A., Sarıca, M. 2007. Alternatif üretim metodu olarak köy tavukçuluğu. 5. Ulusal Zootekni Bilim Kongresi, 5-8 Eylül, Van, s. 189.

Şekeroğlu, A., Sarıca, M. 2010. Bir üretim sistemi olarak köy tavukçuluğu. Tavukçuluk Araştırma Dergisi, 9(1): 41-47.

TÜiK. 2018. Hayvansal Üretim İstatistikleri (Erişim tarihi: 13.02.2017).

Türkoğlu, M., Eleroğlu, H. 1999. Serbest broiler yetiştiriciliği. VIV. Poultry Yutav'99. Uluslararası Tavukçuluk Fuarı ve Konferansı, 3-6 Haziran, İstanbul, s. 110-122.

Yurt, Z. 2002. Çanakkale İlindeki Kimi Köylerde Köy Tipi Kümes Hayvanı Yetiştiriciliğinin Incelenmesi. Yüksek Lisans Tezi, Çanakkale Onsekiz Mart Üniversitesi, Fen Bilimleri Enstitüsü, Çanakkale. 